\title{
Krim ekstrak biji markisa (Pasiflora edulis) sama efektifnya dengan krim hidrokuinon $4 \%$ dalam menghambat peningkatan jumlah melanin pada kulit marmut jantan (Cavia porcelus) yang dipapar sinar UV-B
}

\author{
${ }^{1}$ Siti M. N. Huda, ${ }^{2}$ AAGP Wiraguna, ${ }^{3}$ Wimpie Pangkahila
}

\author{
${ }^{1}$ Program Pascasarjana Anti-Aging Medicine \\ ${ }^{2}$ Departemen Penyakit Kulit dan kelamin \\ ${ }^{3}$ Departemen Andrologi dan Seksologi \\ Fakultas Kedokteran Universitas Udayana Denpasar \\ E-mail: medissanh@gmail.com
}

\begin{abstract}
Ultraviolet B (UVB) ray may cause hyperpigmentation of the skin due to increased melanin level. Passion fruit (Passiflora edulis) is a plant traditionally used to brighten the skin and can give satisfactory result due to its natural tyrosinase and antioxidant activities. This study was aimed to prove that cream of passion fruit extract could prevent the increase of skin melanin in UVB-exposed guinea pig (Cavia porcellus). This was an experimental study using a completely randomized posttest only control group design. Subjects were 30 brown guinea pigs, male, adult (6-8 months old), body weight of 250-300 g, divided into 3 groups as follow: 1) P0, the negative control group, exposed to ultraviolet B and applied with cream based substance; P1, the positive control group, exposed to ultraviolet B and applied with 4\% hydroquinone cream; and P2, the treatment group, exposed to ultraviolet $\mathrm{B}$ and applied $75 \%$ passion fruit extract cream. The results showed that the average amount of melanin in the P0 group was $17.52 \pm 4.72 \%$, whereas in the P1 group was $1.25 \pm 0.45 \%$, and in the P2 group was $1.79 \pm 0.78 \%(P<0.001)$. The LSD test showed that the P0 group had the highest amount of melanin $(P<0.01)$ meanwhile the P1 group had the similar result with the $\mathrm{P} 2$ group $(P>0.05)$. Conclusion: Passion fruit (Passiflora edulis) extract crream could prevent increased skin melanin in UVB-exposed guinea pig (Cavia porcellus) and its effectiveness was similar to those of $4 \%$ hydroquinone cream.
\end{abstract}

Keywords: passion fruit, melanin, UVB, guinea pigs

\begin{abstract}
Abstrak: Paparan sinar ultraviolet B (UVB) mengakibatkan terjadinya kelainan hiperpigmentasi yang ditandai dengan peningkatan jumlah melanin. Markisa (Passiflora edulis) secara tradisional digunakan untuk mencerahkan kulit dan dapat memberikan hasil yang memuaskan karena memiliki aktivitas tirosinase dan antioksidan alamiah. Penelitian ini bertujuan untuk membuktikan bahwa krim ekstrak markisa dapat mencegah peningkatan jumlah melanin kulit marmut (Cavia porcellus) yang dipapar sinar UVB. Jenis penelitian ialah eksperimental menggunakan completely randomized posttest only control group design. Subyek ialah 30 ekor marmut jantan, berwarna coklat, dewasa (usia 6-8 bulan), berat badan 250-300 gr, yang dibagi menjadi 3 (tiga) kelompok masing-masing berjumlah 10 ekor marmut. Kelompok P0 (kelompok kontrol negatif) diberikan penyinaran ultraviolet B dan bahan dasar krim. Kelompok P1 (kelompok kontrol positif) diberikan penyinaran ultraviolet B dan krim hidrokuinon 4\%. Kelompok P2 (kelompok perlakuan) diberikan penyinaran ultraviolet $\mathrm{B}$ dan krim ekstrak markisa 75\%. Hasil penelitian mendapatkan rerata

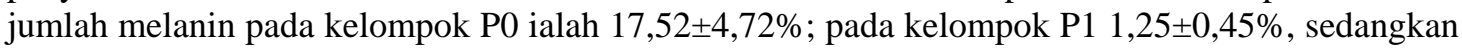
pada kelompok P2 1,79 $\pm 0,78 \%$. Uji LSD menunjukkan bahwa kelompok P0 memiliki jumlah melanin yang paling tinggi $(P<0,01)$, sedangkan kelompok P1 memiliki jumlah melanin yang tidak berbeda nyata dengan kelompok P2 $(P>0,05)$. Simpulan: Krim ekstrak markisa (Passiflora edulis) dapat mencegah peningkatan jumlah melanin kulit marmut (Cavia porcellus) yang dipapar sinar UVB dengan efektifitas yang tidak berbeda dengan krim hidrokuinon $4 \%$.
\end{abstract}

Kata kunci: markisa, melanin, UVB, marmut 
Pembahasan tentang proses menua semakin sering muncul seiring dengan semakin bertambahnya populasi usia lanjut di berbagai belahan dunia. Salah satu tanda penuaan yang mengganggu penampilan ialah timbulnya perubahan warna kulit di wajah berupa bercak coklat atau hitam yang disebut melasma. Melasma ini dapat berdampak yang tidak menyenangkan baik dalam penampilan (fisik), emosional, maupun sosial terutama di kalangan wanita. ${ }^{1}$ Melasma adalah terjadi hiperpigmentasi akibat peningkatan produksi melanin atau peningkatan proliferasi melanosit yang aktif. Peningkatan produksi melanin ini terjadi tanpa perubahan jumlah melanosit. Mekanisme timbulnya melasma yang terjadi dalam proses pembentukan melanin, dapat berupa: peningkatan melanisasi melanosom, pembentukan melanosom yang lebih besar, peningkatan pemindahan melanosom dari melanosit ke keratinosit, serta peningkatan ketahanan melanosom dalam keratinosit. $^{2}$

Dampak psikis dari perubahan warna kulit muka berupa bercak hitam atau coklat di wajah akan menurunkan rasa percaya dan harga dirinya, serta menimbulkan keragu-raguan untuk melakukan hubungan sosial dengan orang lain, yang akan memberi pengaruh pada bidang pekerjaan, sehingga mengakibatkan produktivitas kerja menurun. Banyak cara telah dilakukan untuk mengobati melasma, tetapi belum ada satu carapun yang memuaskan dalam mengobati melasma. Dewasa ini telah banyak produsen obat-obatan serta kosmetik yang berlomba-lomba membuat berbagai macam produk, namun belum ada juga yang berhasil sepenuhnya untuk mengatasi melasma. Berkembangnya kebutuhan masyarakat terutama kaum wanita akan penampilan diri sekaligus estetika, ini membawa arus global pada kemajuan industri peralatan yang berhubungan dengan kesehatan kulit dan kecantikan, obat-obatan topikal maupun sistemik, serta bahan-bahan kosmetik. ${ }^{3}$

Penanggulangan melasma meliputi pengetahuan tentang latar belakang dan penyebab kelainan tersebut, menilai dasar kulit dan menentukan jenis bahan pemutih atau agen depigmentasi, pemilihan tabir surya, tindakan-tindakan lain sebagai alternatif, serta perawatan kulit paska pengobatan. $^{3} \quad$ Penanggulangan melasma yang sulit membuat banyak orang mengambil tindakan lebih baik mencegah dari pada mengobatinya. Salah satu cara untuk mencegah yaitu dengan menggunakan tabir surya serta antioksidan seperti vitamin. Antioksidan alami umumnya banyak terdapat pada buah-buahan dan sayuran dimana banyak mengandung vitamin A, C, E, $\eta 3$ fatty acids, serta nonvitamin tertentu yang terdapat dalam tanaman yang dapat mencegah kerusakan kulit karena penuaan, sinar matahari atau kanker. Banyak penelitian menemukan bahwa antioksidan dapat meningkatkan produksi kolagen, mencegah kerusakan kulit karena UVA dan UVB, mengoreksi masalah pigmentasi pada kulit, serta memperbaiki situasi radang pada kulit. ${ }^{4}$

Antioksidan dalam bentuk topikal yang dioleskan pada permukaan kulit dapat mengurangi efek reactive oxygen species (ROS) dalam menimbulkan kerusakan kulit akibat paparan sinar UV. ${ }^{5}$ Dewasa ini penggunaan antioksidan semakin meningkat, baik secara oral maupun topikal untuk mencegah dan mengobati penuaan kulit. Banyak produk perawatan kulit menggunakan bahan alami yang mengandung antioksidan, baik yang terdapat dalam buah, daun, bunga, akar, dan bagian-bagian lain dari tanaman., Beberapa zat yang mempunyai efek dan fisiologi sebagai antioksidan yaitu: vitamin $\mathrm{C}$, vitamin E, selenium, zinc, silymarin, soy isoflavones, dan tea polyphenols, serta yang mempunyai efek lain sebagai anti karsinogenik. $^{5}$

Biji markisa disebut Passiflora edulis banyak terdapat di Indonesia. Ekstrak biji markisa Passiflora edulis setelah diisolasi mengandung piceatannol dan flavonoid yang memiliki efek menghambat enzim tirosinase dan biosintesis melanin pada sel melanosit. Berdasarkan latar belakang penulisan tersebut, maka penelitian ini dibuat untuk membuktikan bahwa 
piceatanol dan flavonoid yang terdapat pada biji markisa (Passiflora edulis) berefek menghambat proses melanogenesis dengan mencegah peningkatan melanin.

\section{METODE PENELITIAN}

Jenis penelitian ini ialah eksperimental dengan menggunakan completely randomized posttest only control group design. Subyek penelitian ialah 30 ekor marmut (Cavia porcellus) jantan, usia 6-8 bulan dengan berat badan 250-300 gr yang dibagi menjadi 3 kelompok masing-masing berjumlah 10 ekor marmut. Kelompok pertama (P0) ialah kelompok kontrol negatif yang diberikan penyinaran ultraviolet B dan bahan dasar krim; kelompok kedua (P1) ialah kelompok kontrol positif yang diberikan penyinaran ultraviolet B dan krim hidrokuinon 4\%; dan kelompok ketiga (P2) kelompok perlakuan (P2) yang diberikan penyinaran ultraviolet B dan krim ekstrak markisa $75 \%$.

Penelitian dimulai dengan melakukan persiapan, yang meliputi adaptasi marmut dalam kondisi laboratorium selama 7 hari. Perlakuan penelitian ini berlangsung selama 14 hari. Setiap kelompok diberi paparan sinar UVB sebanyak 3 kali seminggu. Setiap paparan diberikan dosis $65 \mathrm{~mJ} / \mathrm{cm}^{2}$ selama 65 detik, Pada hari pemaparan UVB, krim pada setiap kelompok dioles 20 menit sebelum dan 4 jam sesudah paparan sinar UVB. Pada hari tanpa pemaparan UVB, krim tetap dioles 2 kali sehari. Empat puluh delapan jam setelah paparan, marmut dieutanasia menggunakan ketamin dosis berlebih (100 $\mathrm{mg} / \mathrm{kgbb}$ ) secara intraperitoneal. Kulit daerah punggung yang akan diambil, dibersihkan dari bulu kemudian dibuat preparat histopatologik menggunakan pewarnaan Masson-Fontana yang memberi warna hitam pada melanin. Jumlah dihitung dengan persentase pixel luas area melanin dibandingkan dengan pixel seluruh jaringan epidermis.

\section{HASIL PENELITIAN DAN BAHASAN}

Hasil penelitian menunjukkan rerata jumlah melanin pada kelompok kontrol negatif $\mathrm{PO}$ yang diberikan penyinaran ultraviolet $\mathrm{B}$ dan bahan dasar krim ialah 17,52 $44,72 \%$; pada kelompok kontrol positif $\mathrm{P} 1$ yang diberikan penyinaran ultraviolet B dan krim hidrokuinon $4 \%$ ialah $1,25 \pm 0,45 \%$, sedangkan pada kelompok perlakuan P2 yang diberikan penyinaran ultraviolet B dan krim ekstrak markisa $75 \%$ ialah 1,79 $\pm 0,78 \%$ (Gambar 1). Analisis kemaknaan dengan Anova menunjukkan nilai $F=115,895$ dan nilai $P$ $=0,000$. Hal ini berarti ketiga kelompok memiliki rerata jumlah melanin yang berbeda bermakna $(P<0,001)$ (Tabel 1).

Uji lanjutan untuk mengetahui perbedaan individual antar kelompok dengan menggunakan Least Significance Difference (LSD) test menunjukkan bahwa terdapat perbedaan bermakna antara kelompok kontrol negatif dengan kelompok lainnya $(P<0,01)$, dan tidak terdapat perbedaan antara kelompok P1 dengan kelompok P2 $(P \quad>0,05)$. Hal ini menunjukkan bahwa efektivitas krim ekstrak markisa 75\% (P2) dalam mencegah peningkatan melanin pada kulit yang diberikan penyinaran Ultraviolet $\mathrm{B}$ tidak berbeda jika dibandingkan dengan efektivitas krim hidrokuinon 4\% (P1).

Tabel 1. Rerata jumlah melanin antar kelompok

\begin{tabular}{lcccc}
\hline \multicolumn{1}{c}{ Kelompok } & N & $\begin{array}{c}\text { Rerata jumlah } \\
\text { melanin }(\%)\end{array}$ & F & $\boldsymbol{P}$ \\
\hline Kelompok P0 (Krim dasar) & 10 & $17,52 \pm 4,72^{\mathrm{a}}$ & & \\
Kelompok P1 (Hidrokuinon) & 10 & $1,425 \pm 0,45^{\mathrm{b}}$ & 115,895 & 0,000 \\
Kelompok P2 (Krim markisa) & 10 & $1,79 \pm 0,78^{\mathrm{b}}$ & & \\
\hline
\end{tabular}

*Notasi (a, b) yang berbeda menunjukkan berbeda bermakna $(P<0,05)$ 


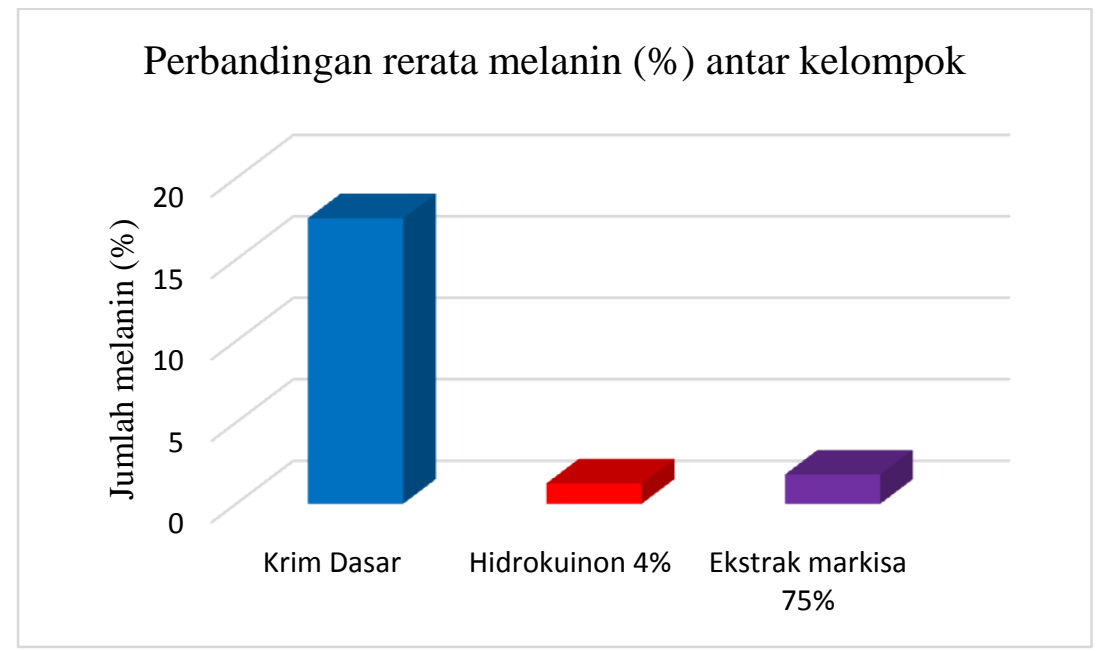

Gambar 1. Perbandingan rerata jumlah melanin antar kelompok

Paparan sinar UVB pada kulit dapat menurunkan efek antioksidan endogen pada semua lapisan kulit seperti glutathione (GSH), superoxide dismutase (SOD), katalase, dan ubiquinol. ${ }^{4}$ Hal ini terjadi karena paparan sinar UVB menghasilkan radikal bebas seperti hydrogen peroxidase, anion superoxide, nitric oxide sehingga dapat menghasilkan ROS. ${ }^{1,8}$

Kerusakan kulit yang disebabkan oleh paparan sinar matahari sangat tergantung dari sering dan lamanya paparan, jenis sinar UV, serta jumlah melanin di kulit (tipe kulit seseorang). Gejala klinis yang dapat terjadi karena photoaging seperti kerut, hipo/hiperpigmentasi, kulit kasar, kulit kering, kulit sagging, atrofi berat, teleangiektasis, elastosis, actinic purpura, lesi prekanker, kanker kulit, dan melanoma. ${ }^{4}$

Radiasi sinar UV meningkatkan pigmentasi kulit melalui beberapa cara antara lain peningkatan kerja enzim melanogenik, peningkatan transfer melanosom menuju keratinosit, peningkatan aktivitas dendritik sel melanosit, dan kerusakan DNA akan menstimulasi proses melanogenesis itu sendiri. ${ }^{9}$ Melanosit dan keratinosit memiliki respon yang sangat cepat terhadap sinar UV, baik secara parakrin maupun autokrin. Paparan sinar UV meningkatkan ekspresi beberpa sitokin, hormon, dan growth factors yang bekerja sebagai sinyal parakrin yang akan ditangkap oleh reseptor permukaan melanosit sehingga akan mengaktifkan jalur terkait sintesis dan distribusi melanin. Paparan sinar UVB meningkatkan jumlah melanosit dan proses melano-genesis. Seluruh spektrum sinar UV akan bereaksi molekul kromofor yang akan menyerap sinar UV ini yaitu molekul purin, pirimidin, serta asam amino triptofan dan tirosin. ${ }^{10}$

Hasil penelitian menunjukkan rerata jumlah melanin pada kelompok kontrol negatif yang diberikan penyinaran ultraviolet B dan bahan dasar krim (P0) ialah 17,52 $\pm 4,72 \%$; pada kelompok kontrol positif yang diberikan penyinaran ultraviolet B dan krim hidrokuinon 4\% (P1) ialah 1,25 $\pm 0,45 \%$; sedangkan pada kelompok perlakuan yang diberikan penyinaran ultraviolet B dan krim ekstrak markisa $75 \%(\mathrm{P} 2)$ ialah $1,79 \pm 0,78 \% \quad(P$ $<0,001)$. Uji lanjutan LSD menunjukkan bahwa terdapat perbedaan bermakna antara kelompok kontrol negatif dan kelompok lainnya $(P<0,01)$, serta tidak terdapat perbedaan antara kelompok P1 dan kelompok P2 $(P>0,05)$. Hal ini menunjukkan bahwa efektivitas krim ekstrak markisa $75 \%$ (P2) dalam mencegah peningkatan melanin pada kulit yang diberikan penyinaran Ultraviolet $\mathrm{B}$ tidak berbeda bermakna dibandingkan dengan efektivitas krim hidrokuinon $4 \%(\mathrm{P} 1)$.

Hidrokuinon (HQ), merupakan baku emas untuk terapi hiperpigmentasi. Konsentrasi mulai dari 2\% hingga kurang dari $10 \%$, telah banyak digunakan untuk 
melasma dan pregnancy-induced hypertension $(\mathrm{PIH})$. Mekanisme kerjanya ialah dengan menghambat kerja enzim tirosinase, merusak sel melanosit langsung, mempercepat degradasi melanosom, dan menghambat sintesis enzim melanogenesis. ${ }^{11}$ Hidrokuinon juga menghambat metabolisme sel secara reversibel dengan memengaruhi kerja sintesis RNA dan DNA. Efek yang dihasilkan agen ini dapat menurunkan lesi hiperpigmentasi hingga $90 \%$.

Hasil penelitian ini menunjukkan bahwa efektifitas hidrokuinon $4 \%$ dalam mencegah peningkatan jumlah melanin sangat potensial. Hal ini mendukung fakta bahwa hidrokuinon memiliki potensi yang sangat bagus sebagai obat untuk hiperpigmentasi. Selain itu, pada kelompok perlakuan yang diberi krim ekstrak markisa $75 \%$ juga dapat diamati potensi efek hipopigmentasi yang sangat potensial. Efek hipopigmentasi ini karena ekstrak markisa merupakan sayuran tropis yang mempunyai aktivitas antioksidan dan anti tirosinase.

Hasil penelitian ini sesuai dengan penelitian in vitro yang pernah dilakukan sebelumnya pada kultur sel melanoma dan fibroblas yang membuktikan bahwa ekstrak etanol markisa 80\% (Passiflora edulis) dapat menghambat melanogenesis. ${ }^{12}$ Penelitian lain oleh Jorge et al. ${ }^{13}$ juga membuktikan bahwa ekstrak markisa (Passiflora edulis) secara bermakna menurunkan sintesis melanin pada kultur sel melanoma mencit (B16) yang diberikan melanocyte-stimulating hormone (MSH). Selain menghambat melanogenesis secara langsung, ekstrak markisa (Passiflora edulis) terbukti dapat melindungi kulit dari kerusakan oksidatif akibat paparan sinar UVB dengan bertindak sebagai antioksidan secara langsung serta menginduksi aktivitas antioksidan endogen seperti glutathione (GSH). ${ }^{14}$

Glutathione (GSH) intrasel berperan penting dalam memroteksi kulit dari stres oksidatif yang diakibatkan oleh berbagai zat kimia dan radiasi UV. Radiasi sinar UV dapat mengurangi kadar GSH dan hal ini memengaruhi patogenesis pada beberapa kelainan kulit. Maruki-Uchida et al. ${ }^{14}$ menunjukkan bahwa piceatannol pada biji markisa dapat meningkatkan kadar GSH intrasel di keratinosit. Piceatannol sebelumnya telah dilaporkan bahwa dapat meningkatkan kadar GSH dalam gel melanoma B16, dimana radiasi sinar UVB tidak mempunyai efek pada kadar GSH melanosit. Hasil penelitian tersebut menunjukkan bahwa peningkatan kadar GSH di keratinosit berperan penting pada proteksi sinar UV pada kulit. ${ }^{14}$

Kandungan flavonoid pada biji markisa dapat bekerja langsung menghambat enzim tirosinase dan juga bekerja pada bagian akhir dari jalur oksidatif melanogenesis, sehingga biji markisa dapat menjadi bahan pencegah timbulnya pigmentasi kulit akibat paparan sinar UV. ${ }^{15}$

Matsui et al. ${ }^{12}$ menemukan bahwa piceatannol (3,4,3', 5'-tetrahidroksi-transstilbene) merupakan komponen utama dari markisa (Passiflora edulis) yang berefek menghambat melanogenesis dan memperlihatkan sprektrum luas pada aktivitas biologik. Piceatannol dapat menghambat aktivitas beberapa faktor transkripsi, termasuk Nuclear Factor Kappa B (NFkB), juga menghambat Janus Kinase 1 (JAK1) dan spleen tyrosine kinase. Bahan ini juga berefek positif pada kultur fibroblas, termasuk inhibisi JAK1 dan jalur signal transducer and activator of transcription (STAT-1), yang menginduksi ekspresi gen MMP-1, menghambat melanogenesis, dan memromosi sintesis kolagen. ${ }^{14}$

Salah satu faktor yang memengaruhi melanogenesis ialah $\alpha$-melanocyte stimulating hormone $(\alpha-\mathrm{MSH})$. Hormon ini berfungsi untuk mengaktifkan tirosinase intrasel yang merupakan enzim yang berperan sangat penting dalam sintesis melanin, yaitu sebagai enzim yang mengatalisis hidroksilasi tirosin menjadi 3,4-dihidroksifenilalanin (DOPA). ${ }^{9}$ Hasil penelitian in vitro menunjukkan bahwa ekstrak metanol markisa (Passiflora edulis) dapat menurunkan sintesis melanin dan sekresi melanin ekstrasel pada kultur sel 
melanoma B16 dengan menghambat aktivasi tirosinase oleh $\alpha$-MSH. ${ }^{16}$

\section{SIMPULAN}

Berdasarkan hasil penelitian ini dapat disimpulkan bahwa krim ekstrak biji markisa (Pasiflora edulis) dapat mencegah peningkatan jumlah melanin kulit mamut (Cavia porcellus) yang dipapar sinar UVB. Krim ekstrak biji markisa memiliki efektivitas yang sama dengan krim hidrokuinon $4 \%$ dalam mencegah peningkatan jumlah melanin kulit marmut yang dipapar sinar UVB.

\section{DAFTAR PUSTAKA}

1. Wiraguna AAGP. Pemberian gel ekstrak bulung boni (Caulerpa spp) topikal mencegah penuaan kulit melalui peningkatan ekspresi kolagen, penurunan kadar dan ekspresi MMP-1 serta ekspresi $8-\mathrm{OHdG}$ pada tikus Wistar yang dipapar sinar ultra violetB [Disertasi]. Denpasar: Universitas Udayana; 2013.

2. Cholis M. Patogenesis melasma. MKI 1995;45:582-7.

3. Wirohadidjoyo YW. Various mechanisme of whitening agent. Naskah Lengkap Simposium Everything about Skin Pigmentation. Jakarta: Kelompok Studi Dermatologi Kosmetik Indonesia (KSDKI) dan Perhimpunan Dokter Spesialis Kulit dan Kelamin Indonesia (PERDOSKI), 2009.

4. Pandel R, Poljsak B, Godic A, Dahmane R. Skin photoaging and the role of antioxidants in its prevention. ISRN Dermatology. 2013;2013. Article ID 930164.

5. Pinnel RS. Cutaneous photodamage, oxidative stress, and topical antioxidant protection, A continuing medical education. J Am Acad Dermatol. 2003;48:1-19.

6. Baumann L, Saghari S. Photoaging. In: Baumann L, Saghari S, Weisberg E, editors. Cosmetic Dermatology (2nd ed). New York: Mc Graw Hill, 2009; p. 34-42.
7. Stalling AS, Lupo MP. Practical uses of botanicals in skin care. J Clin Aesthet Dermatol. 2009; 2(1):36-40.

8. Ichihashi M, Ando H, Yoshida M, Niki Y, Matsui M. Photoaging of the skin. J Anti Aging Med. 2009; 6(6):46-59.

9. Kindred C, Halder R. Pigmentation and skin of Color. In: Draelos ZD, editor. Cosmetic Dermatology Products and Procedures (1st ed). New Jersey: Wiley-Blackwell, 2010; p. 27-35.

10. Costin GE, Hearing VJ. Human skin pigmentation: melanocytes modulate skin color in response to stress. FASEB J. 2007;21(4):976-94.

11. Baumann L, Allemann IB. Antioxidants. In: Baumann L, Saghari S, Weisberg E, editors. Cosmetic Dermatology (2nd ed). New York: Mc Graw Hill, 2009; p. 292-311.

12. Matsui $Y$, Sugiyama $K$, Kamei $M$, Takahashi T, Suzuki T, Katagata Y, Ito T. Extract of passion fruit (Passiflora edulis) seed containing high amounts of piceatannol inhibits melanogenesis and promotes collagen synthesis. J Agric Food Chem. 2010; 58(20):11112-8.

13. Jorge AT, Arroteia KF, Santos IA, Andres E, Medina SP, Ferrari CR, et al. Schinus terebinthifolius Raddi extract and linoleic acid from Passiflora edulis synergistically decrease melanin synthesis in B16 cells and reconstituted epidermis. Int $\mathbf{J}$ Cosmet Sci. 2012; 34(5):435-40.

14. Maruki-Uchida H, Kurita I, Sugiyama K, Sai M, Maeda K, Ito $T$. The protective effects of piceatannol from passion fruit (Passiflora edulis) seeds in UVB-irradiated keratinocytes. Biol Pharm Bull. 2013; 36(5):845-9.

15. Chang TS. An update review of tyrosinase inhibitors. Int J Mol Sci. 2009;10(6): 2440-75.

16. Zhang J, Koike R, Yamamoto A, Ukiya M, Fukatsu M, Banno N, et al. Glycosidic inhibitors of melanogenesis from leaves of Passiflora edulis. Chem Biodivers. 2013;10(10):1851-65. 